\title{
MEDICINAL PLANTS USAGE OF JAGOI BIDAYUH COMMUNITY, BAU DISTRICT, SARAWAK, MALAYSIA
}

\author{
Julan Baling \\ Former student of Plant Resource Science and Management Programme \\ Faculty of Resource Science and Technology \\ Universiti Malaysia Sarawak \\ Kota Samarahan
}

Gabriel T. Noweg, Alexander K. Sayok*, Ik Wadell

Institute of Biodiversity and Environmental Conservation

Universiti Malaysia Sarawak

Kota Samarahan

\author{
Jovita E. Ripen \\ Sarawak Biodiversity Center (SBC), KM12 Penrissen Road, 93250 Kuching, Sarawak \\ *Corresponding author. \\ Email address: ksalexender@ibec.unimas.my
}

\begin{abstract}
This paper reports on the medicinal plants used by the communities near Mount Jagoi in Bau District as part of the multidisciplinary studies in 2012. A total of 58 species of medicinal plants belonging to 38 families were identified and documented. Of these, close to $60 \%$ of these plants are found wild in the fallows and nearby Mount Jagoi forest while the rest are planted at the backyard and/or gardens close to their village. Most of the cultivated medicinal plants were also used as food or often used in their preparation to enhance their flavor. Herbs form the majority (27.6\%) followed by shrubs (24.1\%) and trees (19.0\%). Most of the plants are for treating stomach-related ailments followed by fever-related illnesses as well as treatment of hypertension and cuts/wounds. The main parts of the plants used were foliage or twigs followed by fruits and roots. Decoction was the main method of preparation and administration of the medicinal plants followed respectively by ingestion while pound and rub. The preparation of decoction depends on the types of plant parts used, they can be either fresh or further treatment necessary such as drying to the parts concerned before boiling in water or a mixture with other liquids such as vegetable oil. The mixture after boiling is the decoction, which be used as a drink or used in bathing. The latter use is usually for easing oneself during fever and treatment of the whole body such as to remove bad body odor as well as skin diseases that affect the whole body. It is noteworthy to mention that the study missed six species of medicinal plants from four families that are commonly used for food in the area which could be that the informants were not aware of the medicinal benefits. Should a future survey is being done in a community, it is recommended that the informants be also questioned their knowledge on those obvious plants so that they too can be included.
\end{abstract}

Keywords: Medicinal plants, Bidayuh community, Bau, Mount Jagoi, plant species. 


\section{INTRODUCTION}

According to the World Health Organization (WHO), medicinal plants are any plants which in one or more of its organs contain substances that can be used for therapeutic purposes or which are precursors for chemo-pharmaceutical semi-synthesis. Plant organs that contain medicinal properties are roots, stems, barks, leaves, flowers, fruits and seeds. Plants had been used by mankind as sources of medicine to treat various ailments since time immemorial. Even today, majority of the world populations especially those in rural areas still rely on medicinal plants for healing and to nourish their body for balanced and invigorated well-being (Nissen, 2001).

It has been reported that more than 35,000 plant species worldwide were used in various human cultures for medical purposes (Lewington 1993). Burkill (1966), in his extensive compilation of the economic products of the Malay peninsula, recorded not less than 1,300 plants have been used in traditional medicine. Chai (2006) recorded 608 species of medicinal plants used by 14 ethnic communities in Sarawak. The number could be much higher as knowledge on the indigenous uses of plants was mostly passed on orally from one generation to another and has largely remained undocumented.

Every community has its own knowledge on medicinal plants. Thus the applications of the plants also varied within ethnic group depending on their knowledge, experience and belief toward that particular plant. Indeed based on her studies, Runi (2000) found that the utilization of medicinal plants varies among ethnic groups such as in the ways of preparation and methods for treatment of various ailments and diseases.

Like most rural parts of Sarawak, Jagoi area were used to be predominantly forests where the local communities for generations collect various products for many of their needs. Noweg and Jihen (2005) showed that the Bidayuh community of Bau District are still widely relying on the forest products as a source food, ornaments, religious cultures and traditional medicines. Within Jagoi area, some families even sell these products including medicinal plants at the nearby weekend markets for supplemental income.

But similar to most areas in Bau District, most of Jagoi area had been cleared for shifting cultivation of rice and various crops for decades leaving only patches of uncultivatable lands scattered throughout the area, usually on steep hill slopes and on rocky sides. With the introduction of extensive agriculture activities mainly for oil palm plantation, the rate of clearing in the area has been quite alarming. The only sizeable forested patch of land left in the area is the 400-hectare community land of Mount Jagoi. Some parts of this forest had also been encroached and poaching for wild animals had also increased. Though some measures had been suggested by the Jagoi Area Development Committee (JADC) ${ }^{1}$ to ensure that it will not expand further, it is not a guarantee that much of it will be spared with increasing pressures for more land for various purposes. With the easy sale and increasing demand of the non-timber forest products (NTFP) at the nearby Duyoh market (Toiang, 2016), the pressure is even higher which can cause these products to be more scarce and even extinct. The locals in general regard this community forest as their important heritage and would like to conserve the resources therein. So, to convince the authority to support their aspirations, the JADC in collaboration with Universiti Malaysia Sarawak (UNIMAS) undertook a multidisciplinary assessment to collect data on the sociocultural, natural and biodiversity of the area in 2012 and 2013. The present study formed part of the assessment.

\footnotetext{
${ }^{1}$ A committee comprised elders from each of the nine villages in Jagoi area within the Sarawak part only
} 
The study on medicinal plants formed part of the assessment which aims to document plants used for health and medicinal purposes by the local communities living within Jagoi area. The new information in this study will give additional reasons to support other assessments in getting the forest at Mount Jagoi to be conserved. The information can also form a baseline for further related studies in the area.

\section{METHODOLOGY}

\section{Study site}

The study was conducted in Jagoi area (N 01.358593, E $110.037436^{\circ}$ ), Bau District, some $60 \mathrm{~km}$ south of Kuching City, Sarawak (Figure 1). Approximately at the center of Jagoi area, is a 500-meter high Mount Jagoi. At its saddle, almost three quarters of the way to the summit, is the site of Bung Jagoi village which was home to the ancestors of the Jagoi community who settled there for more than 100 years. The surrounding forest had provided most of their daily needs in terms of food, sustenance and materials for various cultural activities as well as well-being and medicinal apart from housing materials. As the population expanded and demand increase for more crop lands, some 80 years ago the villagers moved down to the surrounding lands, forming nine villages in the Sarawak, Malaysia side and another five villages in nearby West Kalimantan, Indonesia (Sayok et al, 2014).

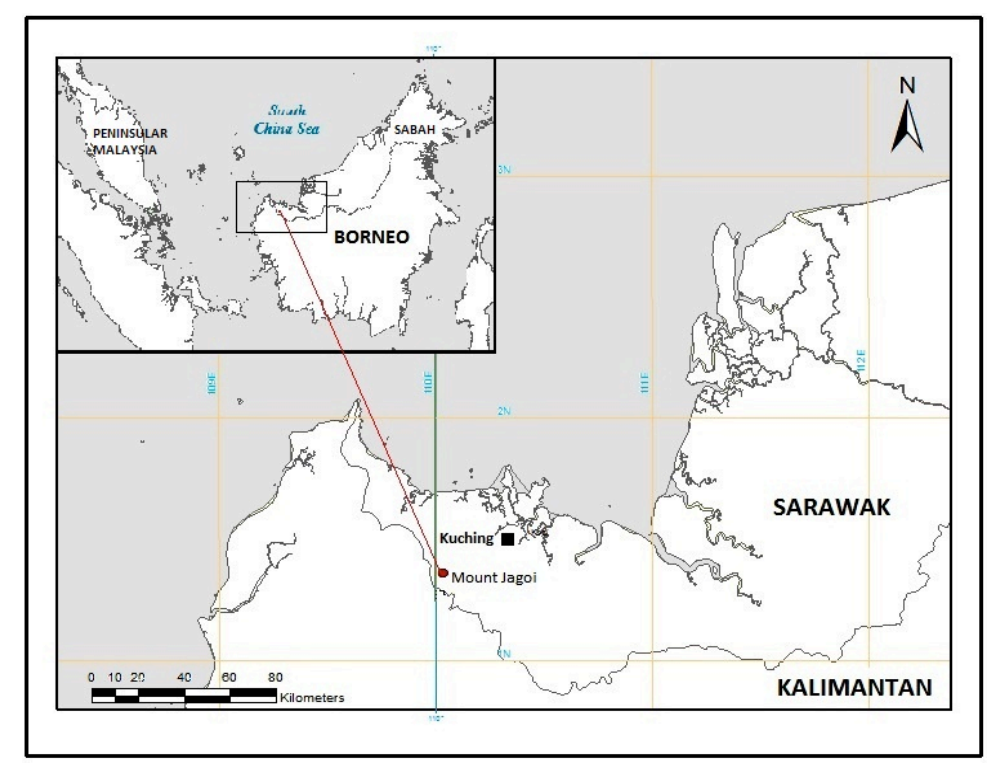

Figure 1. Location of Mount Jagoi, Bau District, Sarawak, Malaysia.

Except for the gentler lands downhill which are basically a mosaic landscape resulting from regrowth at different stages as well as patches of croplands, the area can be categorized into six different forest types depending on the condition of their substrate. The predominantly lowland mixed dipterocarp forests cover the sandy clay loam soils on most of Mount Jagoi while the heath (kerangas) forests cover the sandy hilltop. Limestone forests are found on limestone dominated hills nearby with riparian forests lining the banks of draining streams (Migas, 2013). These forests provide clean water supply to downstream villages apart from housing various important and historical features as well as rich biodiversity. Some locals still depend on the 
forest for daily needs. Forest products such as wild fruits, vegetables and medicinal plants are gathered and sold at the weekend market or 'Tamu' along the roadside at Duyoh Village for an additional income.

In the olden days, most part of Jagoi area are not connected with vehicular roads. So going for basic treatment in the dispensary in Bau Town, some $30 \mathrm{~km}$ away, really involved a big task and time so that only few who could afford sought conventional medical attention. According to Nuek (2005), most rural populations believed that any illnesses and mishaps were acts of evil spirits in retaliation or curses for evil deeds and behaviors of the patients. So they sought the services of witchdoctors (shamans) to cure them. These shamans used various artifacts including a mixture of a few medicinal plants among their chants and beating of gongs and drums. These practices died slowly with the introduction of Christianity and availability of modern medicine. Only a handful of the people still use medicinal plants for various ailments with majority those with age 50 year old and above.

Presently, all villages in Jagoi area is connected by tarsealed roads within Jagoi area and to other areas. There is also a government clinic in Serasot Village for general health and expectant mothers. The distance of the clinic to the furthest village, Serikin, is less than $10 \mathrm{~km}$ or 15-minute drive away. For more serious illnesses and emergencies, patients are usually referred to Bau Hospital in Bau Town, some $30 \mathrm{~km}$ away.

For this study, two villages among the 14 in Jagoi area namely Duyoh Village and Serasot Village were selected as the sites, since they are closer to Mount Jagoi and have much easier access to it compared to the rests. The path or trail from Duyoh Village on the eastern side of the mountain is the main access road to the old mountain village and the summit while that from Serasot Village on the western side is steeper so that it is mainly used by the more challenging climbers.

Duyoh Village has 915 people from 216 households while Serasot 1,289 and 404 respectively ${ }^{2}$. These two villages represented is approximately $27.9 \%$ of those in Bau-Jagoi area (7,539 people from 1,685 households). Both villages are majority of Christian faith $(80 \%)$ but have a small population (18\%) which cling to the old Bidayuh tradition centering their beliefs on spirits and ghosts that can bring peace, harmony and prosperity to the villagers as well as diseases and ailments. The rest came from other religions such as Islam (1\%) and Buddhist $(0.5 \%)$ and Hindu $(0.5 \%)$ who may occasionally take medicinal plants that they know for the same purposes. Only those from Duyoh Village sell medicinal plants at the Duyoh roadside weekend market (Pasar tamu) for extra income. Most of these are planted with a small portion from the nearby forest at Mount Jagoi.

\section{Data collection \& Analysis}

Before data collection were undertaken, a courtesy call was made to the respective headman (ketua kaum) to brief him on our study and then set a date for general discussion with his people. During the discussion, there more than 30 people present ranging from 30 to 70 years old comprising adult villagers, local healers and users of the medicinal plants themselves as well as for treating their family members. From this discussion, some of the participants were selected to participate in the study based on their ability to identify medicinal plants and explain their uses,

\footnotetext{
${ }^{2}$ Data as in 2016 as obtained from District Office Bau
} 
the parts of plants used to treat diseases, types of diseases treated, doses and method of administration.

For the field data collection, the selected informants were brought around to various locations within each of the village to look for medicinal plants that are planted/cultivated such as in pot plants and hedges around the houses as well as backyard gardens, if any. Then surveys were made to identify medicinal plants that are found in the nearby forest (Mount Jagoi). These wild medicinal plants were mainly surveyed along both trails viz from Duyoh village and Serasot Village to the summit of Mount Jagoi. The parameters recorded were plant's local name, part of plant used, method of preparations and their uses. Additionally, interviews with informants were recorded with a tape recorder and photographs of the medicinal plants were taken. These plants were also collected for further identification and for specimens. The collected data was analyzed

for basic statistics using conventional statistical packages to be used for data characterization and interpretations.

\section{RESULTS \& DISCUSSIONS}

\section{Diversity of medicinal plants}

A total of 58 species of medicinal plants were recorded being used by communities from two selected Jagoi villages. Of these, 53 genera and 38 families of plants were included in the study (Table 1). The number of medicinal plant species in the study is just two less than that of Ripen and Noweg (2016) for their study within Jagoi area and similar to those reported by Weety (1997), Noweg and Jihen (2005) and Noweg et. al. (2006). 
Table 1

Medicinal plants used by the Jagoi Bidayuh community of Bau district, Sarawak and their habits and location where they are found

\begin{tabular}{|c|c|c|c|c|c|c|c|c|c|c|c|c|}
\hline \multirow[t]{2}{*}{ No } & \multirow[t]{2}{*}{ Botanical Name } & \multirow{2}{*}{$\begin{array}{c}\text { Local Name } \\
\text { (Bidayuh) }\end{array}$} & \multicolumn{7}{|c|}{ Habit } & \multicolumn{2}{|c|}{ State Found } & \multirow[t]{2}{*}{ Remarks } \\
\hline & & & Shrub & Tree & Herb & $\begin{array}{c}\text { Climber, } \\
\text { Vine, creeper }\end{array}$ & Fern & Palm & $\begin{array}{c}\text { Others } \\
\text { (Grasses, etc) }\end{array}$ & Planted & Wild & \\
\hline & FABACEAE & & & & & & & & & & & \\
\hline 1 & $\begin{array}{l}\text { Archidendron jiringa (Jack) } \\
\text { I.C.Nielsen }\end{array}$ & Joring & & $\mathrm{X}$ & & & & & & $\mathrm{X}$ & $\mathrm{X}$ & \\
\hline 2 & Cassia alata $\mathrm{L}$ & Dowon suluok & $\mathrm{X}$ & & & & & & & & $\mathrm{X}$ & Easily found \\
\hline 3 & Parkia speciosa Hassk & Potah & & $X$ & & & & & & $\mathrm{X}$ & $X$ & \\
\hline 4 & $\begin{array}{l}\text { Spatholobus ferrugineus } \\
\text { (Zoll. \& Moritzi) Benth. } \\
\text { PIPERACEAE }\end{array}$ & Bokah Tibodu & & & & $\mathrm{X}$ & & & & & $\mathrm{X}$ & \\
\hline 5 & Piper betle L. & Dowon bo'id & & & & $\mathrm{X}$ & & & & $X$ & & \\
\hline 6 & Piper caninum Blume & Bo'id gajah & & & & $\mathrm{X}$ & & & & & $X$ & Some planted \\
\hline 7 & Piper nigrum $\mathrm{L}$. & Lada songgot & & & & $\mathrm{X}$ & & & & & & \\
\hline 8 & $\begin{array}{l}\text { Piper porphyrophyllum } \\
\text { N.E.Br } \\
\text { ZINGIBERACEAE }\end{array}$ & Popar doya & & & & $\mathrm{X}$ & & & & & $X$ & \\
\hline 9 & Curcuma domestica Val & Umi'et & & & $X$ & & & & & $\mathrm{X}$ & & Ginger plants \\
\hline 10 & Zingiber cassumunar Roxb & Ngolai & & & $\mathrm{X}$ & & & & & $\mathrm{X}$ & & Ginger plants \\
\hline 11 & Zingiber officinale Rosc. & Ro'ie & & & $\mathrm{X}$ & & & & & $\mathrm{X}$ & & Ginger plants \\
\hline 12 & Alpinia galanga (L.) Willd. & Rikug & & & $\mathrm{X}$ & & & & & $\mathrm{X}$ & & Ginger plants \\
\hline & EUPHORBIACEAE & & & & & & & & & & & \\
\hline 13 & Acalypha hispida Burm.F & Bajou & & & $\mathrm{X}$ & & & & & & $X$ & Easily found \\
\hline 14 & $\begin{array}{l}\text { Macaranga gigantea } \\
\text { Mull.Arg. }\end{array}$ & Badad & $\mathrm{X}$ & & & & & & & & $X$ & Easily found \\
\hline 15 & Manihot esculenta Crantz & Banuok & $\mathrm{X}$ & & & & & & & $\mathrm{X}$ & & $\begin{array}{l}\text { Easily found } \\
\text { wild too }\end{array}$ \\
\hline 16 & $\begin{array}{l}\text { RUBIACEAE } \\
\text { Psychotria viridiflora } \\
\text { Reinw.ex. Blume }\end{array}$ & Pijar & & $\mathrm{X}$ & & & & & & & $\mathrm{X}$ & \\
\hline 17 & Uncaria gambier Roxb & Gomier & & & & $\mathrm{X}$ & & & & & $X$ & Some planted \\
\hline 18 & Morinda citrifolia (Noni) & Bikudu & & $\mathrm{X}$ & & & & & & $\mathrm{X}$ & & \\
\hline
\end{tabular}


Table 1

Medicinal plants used by the Jagoi Bidayuh community of Bau district, Sarawak and their habits and location where they are found (continued)

\begin{tabular}{|c|c|c|c|c|c|c|c|c|c|c|c|c|}
\hline \multirow[t]{2}{*}{ No } & \multirow[t]{2}{*}{ Botanical Name } & \multirow{2}{*}{$\begin{array}{c}\text { Local Name } \\
\text { (Bidayuh) }\end{array}$} & \multicolumn{7}{|c|}{ Habit } & \multicolumn{2}{|c|}{ State Found } & \multirow[t]{2}{*}{ Remarks } \\
\hline & & & Shrub & Tree & Herb & $\begin{array}{c}\text { Climber, } \\
\text { Vine, creeper }\end{array}$ & Fern & Palm & $\begin{array}{c}\text { Others } \\
\text { (grasses, etc) }\end{array}$ & Planted & Forest & \\
\hline & POACEAE & & & & & & & & & & & \\
\hline 19 & Paspalum conjugatum Berg. & Tupai bisina & & & & & & & $\mathrm{X}$ & & $\mathrm{X}$ & Easily found \\
\hline 20 & $\begin{array}{l}\text { Cymbopogon citratus (DC. Ex } \\
\text { Nees) }\end{array}$ & Sorai wangi & & & & & & & $\mathrm{X}$ & $\mathrm{X}$ & & \\
\hline 21 & Imperata cylindrica Beauv. & Lalang & & & & & & & $\mathrm{X}$ & & $\mathrm{X}$ & Easily available \\
\hline $\begin{array}{l}22 \\
23\end{array}$ & $\begin{array}{l}\text { ARECACEAE } \\
\text { Areca catechu } \mathrm{L} \\
\text { Cocos nucifera } \mathrm{L} \text {. }\end{array}$ & $\begin{array}{l}\text { Ba'ai } \\
\text { Kelapak } \\
\text { butan }\end{array}$ & & & & & & $\begin{array}{l}X \\
X\end{array}$ & & $\begin{array}{l}X \\
X\end{array}$ & & \\
\hline & LAMIACEAE & & & & & & & & & & & \\
\hline 24 & Pogostemon auricularius & Bunga dilam & & & $\mathrm{X}$ & & & & & $\mathrm{X}$ & & \\
\hline 25 & $\begin{array}{l}\text { Orthosiphon aristatus } \\
\text { ARACEAE }\end{array}$ & Misai kucing & & & $\mathrm{X}$ & & & & & $\mathrm{X}$ & & Not native \\
\hline 26 & $\begin{array}{l}\text { Homalomena propinqua } \\
\text { Schott. }\end{array}$ & Dowon ulik & & & $\mathrm{X}$ & & & & & & $\mathrm{X}$ & \\
\hline 27 & $\begin{array}{l}\text { Homalomena sagittifolia } \\
\text { Jungh ex Schott } \\
\text { ACANTHACEA }\end{array}$ & Kuduk & & & $\mathrm{X}$ & & & & & & $\mathrm{X}$ & \\
\hline 28 & Andrographis paniculata & Pudun tanak & & & $\mathrm{X}$ & & & & & $\mathrm{X}$ & & \\
\hline 29 & $\begin{array}{l}\text { Justicia gendarussa } \text { Burm. } f \\
\text { ASTERACEAE }\end{array}$ & Pinyongoh & $\mathrm{X}$ & & & & & & & $\mathrm{X}$ & $\mathrm{X}$ & \\
\hline 30 & Ageratum conyzoides L. & Sipotung & & & $\mathrm{X}$ & . & & & & & $\mathrm{X}$ & Easily available \\
\hline 31 & Blumea balsamifera L. D.C. & $\begin{array}{l}\text { Dowon } \\
\text { sisuoh }\end{array}$ & $\mathrm{X}$ & & & & & & & & $\mathrm{X}$ & Easily available \\
\hline 32 & $\begin{array}{l}\text { Lycopodium cernuum L. } \\
\text { (Family: } \\
\text { LYCOPODIACEAE) }\end{array}$ & Sorin ieng & & & & & $\mathrm{X}$ & & & & $\mathrm{X}$ & \\
\hline
\end{tabular}


Table 1

Medicinal plants used by the Jagoi Bidayuh community of Bau district, Sarawak and their habits and location where they are found (continued)

\begin{tabular}{|c|c|c|c|c|c|c|c|c|c|c|c|c|}
\hline \multirow[t]{2}{*}{ No } & \multirow[t]{2}{*}{ Botanical Name } & \multirow{2}{*}{$\begin{array}{l}\text { Local Name } \\
\text { (Bidayuh) }\end{array}$} & \multicolumn{7}{|c|}{ Habit } & \multicolumn{2}{|c|}{ State Found } & \multirow[t]{2}{*}{ Remarks } \\
\hline & & & Shrub & Tree & Herb & $\begin{array}{l}\text { Climber, } \\
\text { Vine, creeper }\end{array}$ & Fern & Palm & $\begin{array}{l}\text { Others } \\
\text { (grasses, etc) }\end{array}$ & Plant & Forest & \\
\hline 33 & $\begin{array}{l}\text { Melastoma malabatrichum L } \\
\text { MELASTOMACEAE }\end{array}$ & Rusak & $\mathrm{X}$ & & & & & & & & $\mathrm{X}$ & Easily available \\
\hline 34 & $\begin{array}{l}\text { Nephenthes ampullaria Jack } \\
\text { NEPENTHACEAE }\end{array}$ & Dowon tiramuo & & & & $X$ & & & & & $\mathrm{X}$ & \\
\hline 35 & $\begin{array}{l}\text { Nephrolepis biserrata (Sw.) } \\
\text { Schott } \\
\text { OLEANDRACEAE }\end{array}$ & Pokuh kubuk & & & & & $\mathrm{X}$ & & & & $\mathrm{X}$ & Easily available \\
\hline 36 & $\begin{array}{l}\text { Pangium edule Reinw. } \\
\text { FLACOURTIACEAE }\end{array}$ & Poyang & & $\mathrm{X}$ & & & & & & $\mathrm{X}$ & & \\
\hline 37 & $\begin{array}{l}\text { Passiflora foetida } \mathrm{L} \text {. } \\
\text { PASSIFLORACEAE }\end{array}$ & $\begin{array}{l}\text { Dowon kelaseh, } \\
\text { Down pok }\end{array}$ & & & & $\mathrm{X}$ & & & & & $\mathrm{X}$ & $\begin{array}{l}\text { Easily found in } \\
\text { open spaces }\end{array}$ \\
\hline 38 & $\begin{array}{l}\text { Plantago major (Plan) } \\
\text { PLANTAGINACEAE }\end{array}$ & Suut kosoung & $\mathrm{X}$ & & & & & & & & $\mathrm{X}$ & $\begin{array}{l}\text { Easily found in } \\
\text { open spaces }\end{array}$ \\
\hline 39 & $\begin{array}{l}\text { Ploiarium alternifolium } \\
\text { Melchior } \\
\text { THEACEAE }\end{array}$ & Sirumah & $\mathrm{X}$ & & & & & & & & $\mathrm{X}$ & \\
\hline 40 & $\begin{array}{l}\text { Psidium guajava Linn } \\
\text { MYRTACEAE }\end{array}$ & Jambu biabas & $\mathrm{X}$ & & & & & & & $\mathrm{X}$ & & Fruit tree \\
\hline 41 & $\begin{array}{l}\text { Scaphium macropodum } \\
\text { Beumee ex K. Heyne } \\
\text { STERCULIACEAE }\end{array}$ & Dowon komang & & $\mathrm{X}$ & & & & & & & $\mathrm{X}$ & \\
\hline 42 & $\begin{array}{l}\text { Aloe vera } \mathrm{L} \\
\text { LILIACEAE }\end{array}$ & Lidah buaya & & & $\mathrm{X}$ & & & & & $\mathrm{X}$ & & Not native \\
\hline 43 & $\begin{array}{l}\text { Annona muuricata } \mathrm{L} \\
\text { ANNONACEAE }\end{array}$ & Dian belanda & & $\mathrm{X}$ & & & & & & $\mathrm{X}$ & & Fruit tree \\
\hline 44 & $\begin{array}{l}\text { Averrhoa carambola L. } \\
\text { OXALIDACEAE }\end{array}$ & Giruming & & $\mathrm{X}$ & & & & & & $\mathrm{X}$ & & Fruit tree \\
\hline
\end{tabular}


Table 1

Medicinal plants used by the Jagoi Bidayuh community of Bau district, Sarawak and their habits and location where they are found (continued)

\begin{tabular}{|c|c|c|c|c|c|c|c|c|c|c|c|c|}
\hline \multirow[t]{2}{*}{ No } & \multirow[t]{2}{*}{ Botanical Name } & \multirow{2}{*}{$\begin{array}{c}\text { Local } \\
\text { Name } \\
\text { (Bidayuh) }\end{array}$} & \multicolumn{7}{|c|}{ Habit } & \multicolumn{2}{|c|}{ State Found } & \multirow[t]{2}{*}{ Remarks } \\
\hline & & & Shrub & Tree & Herb & $\begin{array}{l}\text { Climber, } \\
\text { Vine, creeper }\end{array}$ & Fern & Palm & $\begin{array}{l}\text { Others } \\
\text { (grasses, etc) }\end{array}$ & Garden & Forest & \\
\hline 45 & $\begin{array}{l}\text { Blechnum orientale L. } \\
\text { BLECHNACEAE }\end{array}$ & Sonu & & & & & $\mathrm{X}$ & & & & $\mathrm{X}$ & Easily available \\
\hline 46 & $\begin{array}{l}\text { Centella asiatica }(\mathrm{L} .) \text { Urban } \\
\text { APIACEAE }\end{array}$ & Pigaga & & & $\mathrm{X}$ & & & & & $\mathrm{X}$ & & \\
\hline 47 & $\begin{array}{l}\text { Costus speciosus Koen ex. Retz. } \\
\text { COSTACEAE }\end{array}$ & Sijujut & $\mathrm{X}$ & & & & & & & $\mathrm{X}$ & $\mathrm{X}$ & Easily available \\
\hline 48 & $\begin{array}{l}\text { Curculigo latifolia Dryand } \\
\text { HYPOXIDACEAE }\end{array}$ & Girombang & & & $\mathrm{X}$ & & & & & & $\mathrm{X}$ & \\
\hline 49 & $\begin{array}{l}\text { Vitex pubescens } \\
\text { VERBENACEAE }\end{array}$ & Nyiriwat & & $\mathrm{X}$ & & & & & & & $\mathrm{X}$ & Easily available \\
\hline 50 & $\begin{array}{l}\text { Dillenia suffruticosa Martelli } \\
\text { DILLENIACEAE }\end{array}$ & Buan & $\mathrm{X}$ & & & & & & & & $\mathrm{X}$ & Easily available \\
\hline 51 & $\begin{array}{l}\text { Eurycoma longifolia Jack } \\
\text { SIMAROUBACEAE }\end{array}$ & Tongkat ali & $\mathrm{X}$ & & & & & & & & $\mathrm{X}$ & Some planted \\
\hline 52 & $\begin{array}{l}\text { Ficus grossularioides Burm. f. } \\
\text { MORACEAE }\end{array}$ & Lokan & & & & & & & & & $\mathrm{X}$ & Easily available \\
\hline 53 & $\begin{array}{l}\text { Hibiscus rosa-sinensis } \mathrm{L} . \\
\text { MALVACEAE }\end{array}$ & $\begin{array}{l}\text { Tiruping } \\
\text { siyok }\end{array}$ & $\mathrm{X}$ & & & & & & & $\mathrm{X}$ & & \\
\hline 54 & $\begin{array}{l}\text { Hoya sp. } \\
\text { ASCLEPIADACEAE }\end{array}$ & $\begin{array}{l}\text { Dowon } \\
\text { kapal }\end{array}$ & & & & $\mathrm{X}$ & & & & $\mathrm{X}$ & $\mathrm{X}$ & \\
\hline 55 & $\begin{array}{l}\text { Labisia pumila Benth. \& Hook. f. } \\
\text { MYRSINACEAE }\end{array}$ & $\begin{array}{l}\text { Kacip } \\
\text { fatimah }\end{array}$ & & & $\mathrm{X}$ & & & & & $\mathrm{X}$ & $\mathrm{X}$ & \\
\hline 56 & $\begin{array}{l}\text { Lansium domesticum (Corr.) } \\
\text { Pellegr. } \\
\text { MELIACEAE }\end{array}$ & Lasot & & $\mathrm{X}$ & & & & & & $\mathrm{X}$ & & Fruit tree \\
\hline 57 & $\begin{array}{l}\text { Leucosyke capitellata (Poir.) } \\
\text { Wedd. } \\
\text { URTICACEAE }\end{array}$ & Kerangan & & $\mathrm{X}$ & & & & & & & $\mathrm{X}$ & \\
\hline \multirow[t]{2}{*}{58} & $\begin{array}{l}\text { Pandanus brevifolius } \\
\text { PANDANACEAE }\end{array}$ & $\begin{array}{l}\text { Dowon } \\
\text { pandan }\end{array}$ & & & $\mathrm{X}$ & & & & $\mathrm{X}$ & $\mathrm{X}$ & & Pandan \\
\hline & & TOTAL & 14 & 13 & 16 & 9 & 3 & 2 & 4 & 26 & 32 & \\
\hline
\end{tabular}


Based on family, Fabaceae, Piperaceae and Zingiberaceae were the most dominant families with four species $(6.9 \%)$ each. These are followed closely by Euphorbiaceae, Poaceae and Rubiaceae, each with three species (5.2\%) while Acanthaceae, Annonaceae, Araceae, Arecaceae, Asteraceae and Lamiaceae with two species each (3.5\%). The remainder 26 families were recorded as the least dominant families with a single species each $(1.7 \%)$.

Of the total species, 32 or slightly more than $55 \%$ of the species were found wild ${ }^{3}$ in the area. Although most of these were found along the mountain trails in the forests, included here also are those found among the weeds growing wild in the garden such as Paspalum conjugatum (Tupai Bisina ${ }^{4}$ ) and Imperata cylindrica (Lallang). In fact, more than 31\% (16 species) were found in the nearby open spaces and in the immediate boundary of the garden which can be easily available. Among the later are Passiflora foetida (Dowon Pok), Nephrolepsis biserrata (Pokuh Kubuk), Melastoma malabatrichum (Rusak), Dillenia suffruticosa (Dowon Buan), Ploiarium alternifolium (Sirumah), and Cassia alata (Dowon Sulok). It is also common that poles of D. suffruticosa and P. alternifolium were used inside the gardens as temporary supports for pepper vines and vegetables that climb such as beans and gourds. These two medicinal species (D. suffruticosa and P. alternifolium) can sprout or coppice easily from their poles so that one may mistakenly think that they are grown.

The rest 26 species $(45 \%)$ were planted/cultivated by the local community in various locations such as in flower pots especially the non-native species like Aloe vera (Lidah buaya), Orthosiphon aristatus (Misai Kuching) and Andrographis paniculata (Pudun Tanah) and as hedges around the house such as Hibiscus rosa-chinensis (Bunga Raya). Similar to the situation on wild ones above, there are some species that were planted such as Manihot esculenta (Banuok) which were found also found in the fallows and immediate boundary of the gardens as this species easily formed their roots from discarded cuttings and not only grow but produce tubers nearly as good as the cultivated ones.

There seemed to be not really much difference in the number of cultivated species found between the backyard garden and the nearby owners' garden. They varied from participant to the next, and most said they just planted them as they like. Most of the cultivated species were found in the garden Most are found in their backyard gardens and found to be more commonly or frequently used by the locals only for medicines and health but as food as well in terms of vegetable such as shoots/ foliage for "ulam", edible fruits and nuts. Although not registered as cultivated in this study because they were not commonly practiced, three wild plants were found planted in small numbers in the two villages namely Eurycoma longifolia (Tongkat Ali), Labisia pumila (Kacip Fatimah), Uncaria gambier (Gomier), Phaleria macrocarpa (Buah Mahkota Dewa, F. Thymelaeaceae). These may be because these plants are getting more popular so that these are just a recent move.

Quite surprisingly, Carica papaya (Betek ${ }^{5}, \mathrm{~F}$ : Caricaceae) whereby its young leaves are used for hypertension, this survey did not register this species though it is common in backyard gardens of both villages. Its ripe fruits are eaten when ripe like any other tropical fruits. Unripe fruits can be cooked as vegetables while the young leaves are eaten during meals as "ulam". The same case for other medicinal plants with edible parts like Averhoa bilimbi (Belimbing besi, F: Oxalidaceae) which is used for treatment of jaundice and hypertension (Salma et al, 2011) although there are at least two trees found right at the entrance of the old mountain village, thus not easily to be missed. The other common medicinal species found around homes and gardens are Capsicum frutesecens (Saang piit) and Solanum torvun (Tiyung jakang). The latter species and Physalis minima L. (Ratuok) (Chai, 2006) are also found commonly wild in open fallows and even in gardens. All three species are from Family Solanaceae. The main reason for missing these plants could be that the villagers did not use them also for medical purposes. With these six included, the species should be at least 64 species of medicinal plants from 43 Families at the two villages in Jagoi Area.

\footnotetext{
${ }^{3}$ Wild here refers to species that were not planted, even if they grow by themselves inside a cultivated area.

${ }^{4}$ Common names are in Bidayuh Bau-Jagoi as per Table 1.

${ }^{5}$ Common names are also in Bidayuh Bau-Jagoi
} 


\section{Type of medicinal plants}

The medicinal plants in the study varies in terms of habits which can be generally categorized into six as herbs, trees, shrubs, climbers, palms, ferns, and others (Figure 2). In this study, those considered as climbers also include all vines and creepers, though the later do not climb above the ground level. Those recorded under others are the grasses and grass-like plants such as Pandanus sp. Based on this method of categorizing the plants, 16 species $(27.6 \%)$ of out of 58 were herbs, 14 shrubs (24.1\%), 11 trees $(19.0 \%)$, and 9 climbers (15.5\%). Medicinal source derived from only two palms were considered the least (3.4\%). The composition is quite similar to those obtained by Noweg and Jihen (2005) in Bau District.

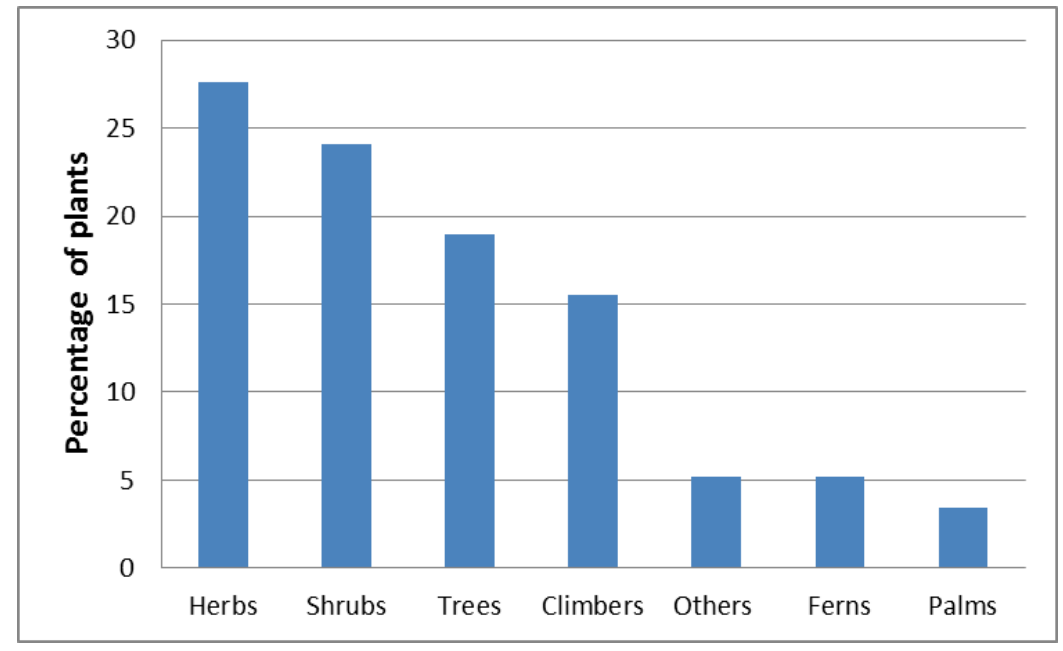

Figure 2. Composition of Plant Types/Habits

\section{Medicinal plants usage, parts used and method of preparation/administration}

Data on the uses of the respective medicinal plants, their parts used and method of preparing as well as administrating them to the patient are shown in Table 2. Further details on each of these are discussed in their respective subsection below.

\section{Usage of the medicinal plants}

Based on the informants from the two villages, one medicinal plant can be used for treatment of a few kinds of ailments and diseases such as Aloe vera (Lidah Buaya) for treating hypertension, skin itches, boils and burns. Also the same kind of ailments and diseases can be treated by a few plants. Among them is hypertension which can be remedied by Aloe vera, Andrographis paniculata, Annona muuricata, Archidendron jiringa, and Centella asiatica either singly or in. 
Table 2

Medicinal plants used, parts used and method of preparation/ administration by the Jagoi community (continued)

\begin{tabular}{|c|c|c|c|c|}
\hline No & Botanical Name & Medicinal Uses & Parts used & Method of Preparation \\
\hline 1. & $\begin{array}{l}\text { Acalypha hispida } \\
\text { Burm. F }\end{array}$ & To relief tooth ache & Stem & $\begin{array}{l}\text { The stem is heated over a fire to encourage } \\
\text { sap coming out of the bark. The sap is left to } \\
\text { cool down (turns black when cold) and put } \\
\text { on affected teeth to relief aches }\end{array}$ \\
\hline 2. & $\begin{array}{l}\text { Ageratum conyzoides } \\
\text { L. }\end{array}$ & $\begin{array}{l}\text { To remove excess } \\
\text { wind from the body }\end{array}$ & Foliage $^{6}$ & $\begin{array}{l}\text { The young foliage is boiled together with } \\
\text { Piper betle and the decoction can be drunk. }\end{array}$ \\
\hline 3. & $\begin{array}{l}\text { Alpinia galanga }(\mathrm{L} .) \\
\text { Willd. }\end{array}$ & $\begin{array}{l}\text { To treat dhobi's itch } \\
\text { (panau), fever and } \\
\text { remove excess wind } \\
\text { (flatulent) from the } \\
\text { body }\end{array}$ & Rhizome $^{7}$ & $\begin{array}{l}\text { The rhizomes are grated and rubbed onto the } \\
\text { affected parts. For mothers after recent child } \\
\text { birth, the rhizome are usually pound and rub } \\
\text { over the whole body. The rhizomes are also } \\
\text { used as spices and flavor in various dishes. }\end{array}$ \\
\hline 4. & Aloe vera $\mathrm{L}$ & $\begin{array}{l}\text { To alleviate } \\
\text { hypertension, itches, } \\
\text { boils and burns }\end{array}$ & Foliage & $\begin{array}{l}\text { 1) Chopped the young foliage into smaller } \\
\text { pieces and boiled. Drink the decoction. 2) } \\
\text { For external uses, the clear sap from the } \\
\text { leaves is applied to the affected skin. }\end{array}$ \\
\hline 5. & $\begin{array}{l}\text { Andrographis } \\
\text { paniculata L. }\end{array}$ & $\begin{array}{l}\text { To relieve fever, } \\
\text { stomach-ache, } \\
\text { hypertension and } \\
\text { diabetes }\end{array}$ & Foliage & $\begin{array}{l}\text { The young foliage need to be boiled. Then } \\
\text { the decoction can be drunk. }\end{array}$ \\
\hline 6. & Annona muuricata $\mathrm{L}$ & $\begin{array}{l}\text { To lower down } \\
\text { hypertension }\end{array}$ & Flower & $\begin{array}{l}\text { The flowers can be boiled and drink the } \\
\text { decoction }\end{array}$ \\
\hline 7. & $\begin{array}{l}\text { Archidendron jiringa } \\
\text { (Jack) I.C.Nielsen }\end{array}$ & $\begin{array}{l}\text { To alleviate } \\
\text { hypertension, } \\
\text { diabetes }\end{array}$ & $\begin{array}{l}\text { Fruit(beans), } \\
\text { leaf }\end{array}$ & $\begin{array}{l}\text { Boil the young leaves or immature fruits. } \\
\text { Decoction can be made into drink. The } \\
\text { young leaves and mature fruits can also be } \\
\text { eaten as 'ulam' }\end{array}$ \\
\hline 8. & Areca catechu $\mathrm{L}$ & $\begin{array}{l}\text { To relief stomach- } \\
\text { ache and heal wound }\end{array}$ & Fruit & $\begin{array}{l}\text { The mature fruits are cut into small pieces } \\
\text { and boiled to make a drink. They can also be } \\
\text { chewed with lime and Piper betle leaf, the } \\
\text { mixture can be put on cuts/wounds to heal. }\end{array}$ \\
\hline 9. & Averrhoa carambola $\mathrm{L}$. & To treat hypertension & Leaf, fruits & $\begin{array}{l}\text { The young leaves are crushed and added into } \\
\text { warm water to make a drink. The fruits can } \\
\text { be eaten and juice as health drink. }\end{array}$ \\
\hline 10. & Blechnum orientale $\mathrm{L}$. & $\begin{array}{l}\text { To cure carbuncle } \\
\text { (boil) }\end{array}$ & $\begin{array}{l}\text { Young shoot } \\
\text { (fiddle) }\end{array}$ & $\begin{array}{l}\text { The young shoot (fiddle head) is pound and } \\
\text { bandage on the affected area/boil to } \\
\text { stimulate it to burst }\end{array}$ \\
\hline 11. & $\begin{array}{l}\text { Blumea balsamifera } \mathrm{L} \text {. } \\
\text { D.C. }\end{array}$ & $\begin{array}{l}\text { Fever, mother after } \\
\text { delivery, treatment of } \\
\text { kidney disorders }\end{array}$ & Foliage & $\begin{array}{l}\text { Boil the foliage and drink decoction. For } \\
\text { mothers after delivery, use the warm } \\
\text { solution for bath to give better bodily odour. }\end{array}$ \\
\hline 12. & $\begin{array}{l}\text { Centella asiatica }(\mathrm{L} .) \\
\text { Urban }\end{array}$ & $\begin{array}{l}\text { To alleviate } \\
\text { hypertension }\end{array}$ & Leaf & Boil the leaves and drink decoction. \\
\hline 13. & Cocos nucifera $\mathrm{L}$. & $\begin{array}{l}\text { To treat skin rashes, } \\
\text { jaundice in newborn } \\
\text { baby }\end{array}$ & Fruit & $\begin{array}{l}\text { Coconut water is used to give baby bath to } \\
\text { treat skin rashes and jaundice. The mature } \\
\text { fruit is grated and soaked with water. The } \\
\text { upper layer is full of rich oil which is } \\
\text { consumed to clean the intestine when taken } \\
\text { regularly. }\end{array}$ \\
\hline
\end{tabular}

\footnotetext{
${ }^{6}$ Foliage or twig is made of young leaves and stem

${ }^{7}$ Rhizomes, roots and tubers refers here to mean the underground part of the plants wherever as applicable
} 
Table 2

Medicinal plants used, parts used and method of preparation/ administration by the Jagoi community (continued)

\begin{tabular}{|c|c|c|c|c|}
\hline No & Botanical Name & Medicinal Uses & Parts used & Method of Preparation \\
\hline 14 & $\begin{array}{l}\text { Costus speciosus Koen } \\
\text { ex. Retz. }\end{array}$ & $\begin{array}{l}\text { To treat fever, rashes and } \\
\text { asthma }\end{array}$ & Rhizome & $\begin{array}{l}\text { 1) For fever and asthma, the rhizome are } \\
\text { chopped into small pieces and boiled. } \\
\text { The decoction is then drank. 2) For } \\
\text { rashes, the decoction is used for bathing. }\end{array}$ \\
\hline 15 & $\begin{array}{l}\text { Curculigo latifolia } \\
\text { Dryand }\end{array}$ & For hypertension & Leaf & $\begin{array}{l}\text { Boiled the leaves to make a drink } \\
\text { regularly }\end{array}$ \\
\hline 16 & $\begin{array}{l}\text { Curcuma domestica } \\
\text { Val }\end{array}$ & $\begin{array}{l}\text { To treat and kill parasites } \\
\text { and worms in the stomach, } \\
\text { to treat wound and } \\
\text { diarrhoea }\end{array}$ & $\begin{array}{l}\text { Leaf, } \\
\text { rhizome }\end{array}$ & $\begin{array}{l}\text { Pound the rhizome and drink the juice to } \\
\text { treat stomach-ache. For wound, pound } \\
\text { the rhizome and rub onto the affected } \\
\text { area. The young leaves can be eaten as } \\
\text { "ulam" and food flavoring especially in } \\
\text { fish dishes }\end{array}$ \\
\hline 17 & $\begin{array}{l}\text { Cymbopogon citratus } \\
\text { (DC. Ex Nees) }\end{array}$ & $\begin{array}{l}\text { To loss body smell and to } \\
\text { lower body temperature }\end{array}$ & Stem & $\begin{array}{l}\text { Boil the stem and the decoction of the } \\
\text { plant is used for bathing }\end{array}$ \\
\hline 18 & $\begin{array}{l}\text { Dillenia suffruticosa } \\
\text { Martelli }\end{array}$ & $\begin{array}{l}\text { To treat cuts and wounds, } \\
\text { ringworm }\end{array}$ & Leaf & $\begin{array}{l}\text { Pound or chew the young leaves and rub } \\
\text { onto the affected area. Young leaves can } \\
\text { also be eaten as "ulam }\end{array}$ \\
\hline 19 & $\begin{array}{l}\text { Eurycoma longifolia } \\
\text { Jack }\end{array}$ & To alleviate hypertension & $\begin{array}{l}\text { Roots } \\
\text { Leaf, }\end{array}$ & $\begin{array}{l}\text { Boil a few leaves to make a drink to } \\
\text { relief hypertension. Roots are crushed } \\
\text { and mainly used in drink for health. }\end{array}$ \\
\hline 20 & $\begin{array}{l}\text { Ficus grossularioides } \\
\text { Burm. f. }\end{array}$ & $\begin{array}{l}\text { To treat skin infections } \\
\text { such as scabies and } \\
\text { shingles or kayap }\end{array}$ & $\begin{array}{l}\text { Stem' } \\
\text { fruits }\end{array}$ & $\begin{array}{l}\text { The stem or fruits are cut off to get the } \\
\text { whitish latex and is applied on the skin. } \\
\text { Fruits can also be eaten. }\end{array}$ \\
\hline 21 & $\begin{array}{l}\text { Hibiscus rosa- sinensis } \\
\text { L. }\end{array}$ & To relief headache & stem & $\begin{array}{l}\text { Pounded the leaves and poultice the } \\
\text { forehead }\end{array}$ \\
\hline 22 & $\begin{array}{l}\text { Homalomena } \\
\text { propinqua Schott. }\end{array}$ & To treat cut and wound & Tuber & $\begin{array}{l}\text { Pound the tuber and apply onto affected } \\
\text { part }\end{array}$ \\
\hline 23 & $\begin{array}{l}\text { Homalomena } \\
\text { sagittifolia Jungh ex } \\
\text { Schott }\end{array}$ & $\begin{array}{l}\text { To treat gastric and joint } \\
\text { pain }\end{array}$ & Rhizome & $\begin{array}{l}\text { The rhizomes are cut into small pieces } \\
\text { about } 1 \mathrm{~cm} \text { and dried under the sunlight. } \\
\text { It can be added into a hot water and as a } \\
\text { drink }\end{array}$ \\
\hline 24 & Hoys sp. & $\begin{array}{l}\text { To alleviate hypertension } \\
\text { and diabetes }\end{array}$ & Leaf & $\begin{array}{l}\text { Boil the leaves and drink the decoction } \\
\text { or the leaves can be dried to make as a } \\
\text { tea. The leaves can be taken raw as } \\
\text { "ulam". }\end{array}$ \\
\hline 25 & $\begin{array}{l}\text { Imperata cylindrica } \\
\text { Beauv. }\end{array}$ & To stop bleeding & $\begin{array}{l}\text { Rhizome } \\
\text { with it } \\
\text { roots }\end{array}$ & $\begin{array}{l}\text { The young roots are pound and rubbed } \\
\text { onto the affected area }\end{array}$ \\
\hline 26 & $\begin{array}{l}\text { Justicia gendarussa } \\
\text { Burm. } f\end{array}$ & $\begin{array}{l}\text { To treat backaches, bone } \\
\text { fractures, sprains and cuts }\end{array}$ & Leaf & $\begin{array}{l}\text { Pound the leaves and apply onto the back } \\
\text { and also the fresh leaves can be eaten as } \\
\text { vegetables regularly }\end{array}$ \\
\hline 27 & $\begin{array}{l}\text { Labisia pumila Benth. } \\
\& \text { Hook. f. }\end{array}$ & To alleviate high fever & $\begin{array}{l}\text { Whole } \\
\text { plant }\end{array}$ & $\begin{array}{l}\text { Boil the whole plant parts. Use a } \\
\text { decoction in the bath. The plant can also } \\
\text { be dried and pound to powder to make } \\
\text { health drink for women }\end{array}$ \\
\hline 28 & $\begin{array}{l}\text { Lansium domesticum } \\
\text { (Corr.) Pellegr. }\end{array}$ & $\begin{array}{l}\text { To treat stomach-ache, and } \\
\text { fever }\end{array}$ & Seed, leaf & $\begin{array}{l}\text { 1) Pound the seed and add warm water to } \\
\text { cure stomach ache. 2) A decoction of the } \\
\text { leaves can be taken to lessen fever }\end{array}$ \\
\hline 29 & $\begin{array}{l}\text { Leucosyke capitellata } \\
\text { (Poir.) Wedd. }\end{array}$ & $\begin{array}{l}\text { To lower the high body } \\
\text { temperature }\end{array}$ & Leaf & $\begin{array}{l}\text { The leaves are dried and added with } \\
\text { water to make tea }\end{array}$ \\
\hline
\end{tabular}




\begin{tabular}{|c|c|c|c|c|}
\hline 30 & $\begin{array}{l}\text { Lycopodium cernuum } \\
\text { L. }\end{array}$ & To treat skin injury, stroke & $\begin{array}{l}\text { Whole } \\
\text { plant }\end{array}$ & $\begin{array}{l}\text { 1) The plant with any other plant will be } \\
\text { fanned on the patient's body while the } \\
\text { shaman giving an appropriate chant. The } \\
\text { person with a stroke is said be healed and } \\
\text { get up instantly. 2) The whole plant can } \\
\text { be chewed and put on to the wounds. }\end{array}$ \\
\hline 31 & $\begin{array}{l}\text { Macaranga gigantea } \\
\text { Mull.Arg. }\end{array}$ & Gastric (dugal) & Bark & $\begin{array}{l}\text { The outer bark is to be boiled together } \\
\text { with Nepenthes ampularia, Blechnum } \\
\text { orientale and Spatolobus sp. The } \\
\text { decoction is then drank regularly }\end{array}$ \\
\hline 32 & $\begin{array}{l}\text { Manihot esculenta } \\
\text { Crantz }\end{array}$ & $\begin{array}{l}\text { To cleanse the intestine, } \\
\text { mitigate headache and } \\
\text { upset stomach }\end{array}$ & Tuber & $\begin{array}{l}\text { Wash and boil the tuber then add a pinch } \\
\text { of salt. It can be consumed as food too }\end{array}$ \\
\hline 33 & $\begin{array}{l}\text { Melastoma } \\
\text { malabatrichum } \mathrm{L}\end{array}$ & To stop bleeding, wound & Leaf & $\begin{array}{l}\text { The leaves are crushed and applied onto } \\
\text { the affected area }\end{array}$ \\
\hline 34 & $\begin{array}{l}\text { Morinda citrifolia } \\
\text { (Noni) }\end{array}$ & $\begin{array}{l}\text { To alleviate hypertension } \\
\text { and alleviate cough }\end{array}$ & $\begin{array}{l}\text { Fruit, } \\
\text { leaves }\end{array}$ & $\begin{array}{l}\text { Boil the fruits to make a drink, squeeze } \\
\text { the juice from the ripe fruit to treat } \\
\text { cough, young leaves can be eaten as } \\
\text { 'ulam' and cook with meat. }\end{array}$ \\
\hline 35 & $\begin{array}{l}\text { Nephenthes ampullaria } \\
\text { Jack }\end{array}$ & Gastric (dugal) & Shoot & $\begin{array}{l}\text { Young shoot boil with Macaranga } \\
\text { gigantea and Spatholobus ferrugineus. } \\
\text { Drink the decoction of the plants. }\end{array}$ \\
\hline 36 & $\begin{array}{l}\text { Nephrolepis biserrata } \\
\text { (Sw.) Schott }\end{array}$ & $\begin{array}{l}\text { Remove excess wind from } \\
\text { the body and to stimulate } \\
\text { the flow of milk in mother } \\
\text { afterbirth }\end{array}$ & Shoot & $\begin{array}{l}\text { Boil the young shoot to make a soup and } \\
\text { be taken during meal. }\end{array}$ \\
\hline 37 & Orthosiphon aristatus & To relief joint pain & Leaf & Boil the leaves and drink the decoction \\
\hline 38 & Pandanus brevifolius & $\begin{array}{l}\text { To remove toxins from the } \\
\text { body }\end{array}$ & Leaf & $\begin{array}{l}\text { The leaves are chopped into small pieces } \\
\text { and boiled. The decoction can be } \\
\text { regularly drank to remove toxin from the } \\
\text { body. The young leaves can also be used } \\
\text { for food flavoring }\end{array}$ \\
\hline 39 & Pangium edule Reinw. & To treat wound & Leaf, fruit & $\begin{array}{l}\text { Leaves dried and pound to be applied } \\
\text { onto the wound. The fruit when raw is } \\
\text { very poisonous but can be eaten when } \\
\text { thoroughly boiled and rinsed overnight in } \\
\text { flowing water. }\end{array}$ \\
\hline 40 & Parkia speciosa Hassk & $\begin{array}{l}\text { Treatment against liver } \\
\text { diseases, worms, } \\
\text { hypertension and diabetes }\end{array}$ & Fruit, Leaf & $\begin{array}{l}\text { Boil the young leaves and drink the } \\
\text { decoction. Fruits are eaten as "ulam" and } \\
\text { in cooking }\end{array}$ \\
\hline 41 & $\begin{array}{l}\text { Paspalum conjugatum } \\
\text { Berg. }\end{array}$ & To stop bleeding & Leaf & $\begin{array}{l}\text { Pound the young leaf and apply onto the } \\
\text { wound }\end{array}$ \\
\hline 42 & Passiflora foetida $\mathrm{L}$. & To alleviate constipation & Leaf, fruit & $\begin{array}{l}\text { Boil the leaves to make a drink. They can } \\
\text { also be used as "ulam". The ripe fruit can } \\
\text { be eaten similar to passion fruit. }\end{array}$ \\
\hline 43 & Piper betle L. & $\begin{array}{l}\text { For invigorate after } \\
\text { childbirth and to treat fever }\end{array}$ & Leaf & $\begin{array}{l}\text { Boil the leaves in a big pot then place } \\
\text { under a chair while mother is sitting on } \\
\text { the chair. }\end{array}$ \\
\hline 44 & Piper caninum Blume & To alleviate hypertension & Leaf & $\begin{array}{l}\text { Boil the leaves to make a drink. Young } \\
\text { leaves are also used as "ulam". }\end{array}$ \\
\hline 45 & Piper nigrum L. & $\begin{array}{l}\text { To remove excess wind } \\
\text { (flatulent) }\end{array}$ & berries & $\begin{array}{l}\text { Takes } 6 \text { seeds and chewed and drink } 1 \\
\text { glass of warm plain water. Fruits are } \\
\text { used in seasoning food. }\end{array}$ \\
\hline 46 & $\begin{array}{l}\text { Piper porphyrophyllum } \\
\text { N.E.Br }\end{array}$ & $\begin{array}{l}\text { To remove blood clotting } \\
\text { in the uterus after } \\
\text { childbirth, to cure bruises }\end{array}$ & Leaf & $\begin{array}{l}\text { Warm the leaves over a fire and apply on } \\
\text { the abdomen of the mother and apply } \\
\text { onto bruises }\end{array}$ \\
\hline
\end{tabular}




\begin{tabular}{|c|c|c|c|c|}
\hline 47 & Plantago major (Plan) & $\begin{array}{l}\text { To treat headaches, } \\
\text { diarrhoea, dysentery, } \\
\text { stomach ulcers, and } \\
\text { bladder infections }\end{array}$ & Leaf & Boil the leaves to make a drink. \\
\hline 48 & $\begin{array}{l}\text { Ploiarium alternifolium } \\
\text { Melchior }\end{array}$ & $\begin{array}{l}\text { Remove excess wind for } \\
\text { baby, can consumed as } \\
\text { food }\end{array}$ & Leaf & $\begin{array}{l}\text { Boiled the leaves and the solution used } \\
\text { for baby bathing, the fresh young leaves } \\
\text { are can be eaten as 'ulam' (sour taste) or } \\
\text { can be cooked with fish }\end{array}$ \\
\hline 49 & $\begin{array}{l}\text { Pogostemon } \\
\text { auricularius }\end{array}$ & $\begin{array}{l}\text { To alleviate hypertension } \\
\text { and headache }\end{array}$ & Leaf & $\begin{array}{l}\text { Boiled the leaves to make a drink or the } \\
\text { solution used as shampoo }\end{array}$ \\
\hline 50 & Psidium guajava Linn & $\begin{array}{l}\text { To cure dysentery, } \\
\text { diarrhoea, remove excess } \\
\text { wind from the body }\end{array}$ & Leaf, fruit & $\begin{array}{l}\text { Boil the young leaves to make a drink. } \\
\text { Ripe fruit can be eaten }\end{array}$ \\
\hline 51 & $\begin{array}{l}\text { Psychotria viridiflora } \\
\text { Reinw.ex. Blume }\end{array}$ & For healing wound & Leaf & $\begin{array}{l}\text { Pound the leaves and apply onto the } \\
\text { wound. It also experience to treat the } \\
\text { major cuts and wounds. Apply } 4-5 \text { times } \\
\text { a day }\end{array}$ \\
\hline 52 & $\begin{array}{l}\text { Scaphium } \\
\text { macropodum Beumee } \\
\text { ex K. Heyne }\end{array}$ & $\begin{array}{l}\text { To mitigate diarrhoea, } \\
\text { dysentery and asthmatic } \\
\text { complaints }\end{array}$ & Seed & $\begin{array}{l}\text { The seeds of the plants are soaked in a } \\
\text { water for a night. The water then is used } \\
\text { for drink }\end{array}$ \\
\hline 53 & $\begin{array}{l}\text { Spatholobus } \\
\text { ferrugineus (Zoll. \& } \\
\text { Moritzi) Benth. }\end{array}$ & Gastric (dugal) & Shoot & $\begin{array}{l}\text { Boil the young shoot together with } \\
\text { Nephentes ampularia, Blechnum } \\
\text { orientale and Macaranga gigantea. } \\
\text { Drink the decoction. }\end{array}$ \\
\hline 54 & Uncaria gambier Roxb & $\begin{array}{l}\text { To cure cuts and wound, } \\
\text { headache and stomach } \\
\text { ache }\end{array}$ & Leaf & $\begin{array}{l}\text { Dried leaves need to be mixed with Piper } \\
\text { betle leaf, lime and Areca catechu and } \\
\text { apply on the affected part }\end{array}$ \\
\hline 55 & Vitex pubescens & $\begin{array}{l}\text { To relieve excess wind } \\
\text { from the body and gastric }\end{array}$ & Leaf & $\begin{array}{l}\text { Boiled the leaves to make a drink, the } \\
\text { young leaves can be eaten as 'ulam' }\end{array}$ \\
\hline 56 & $\begin{array}{l}\text { Zingiber cassumunar } \\
\text { Roxb }\end{array}$ & $\begin{array}{l}\text { Used for massage mother } \\
\text { after childbirth to remove } \\
\text { excess wind and improve } \\
\text { blood circulation }\end{array}$ & Rhizome & $\begin{array}{l}\text { Pound the rhizome and massage over the } \\
\text { body with an oil of the rhizome }\end{array}$ \\
\hline 57 & $\begin{array}{l}\text { Zingiber officinale } \\
\text { Rosc. }\end{array}$ & $\begin{array}{l}\text { Remove wind from the } \\
\text { body, gastric, treatment for } \\
\text { mother after delivery }\end{array}$ & $\begin{array}{l}\text { Rhizome, } \\
\text { Leaves }\end{array}$ & $\begin{array}{l}\text { The rhizome are pounded and steam } \\
\text { about 2-3 hours or can be cut into small } \\
\text { pieces and dried to added into a hot } \\
\text { water as a drink by mother after } \\
\text { childbirth. Young leaves are used as } \\
\text { "ulam" while the rhizomes are also used } \\
\text { in various dishes }\end{array}$ \\
\hline
\end{tabular}

combination of other medicinal plants. Some diseases too may require a combination of a few plants to be used for remedy. For example, when using Macaranga gigantea (Badad) to treat gastric, its outer bark is to be boiled together with Nepenthes ampularia (Tramuok), Blechnum orientale (Sonu) and Spatolobus sp. (Gomier). Furthermore, many of these ailments too have different names based on the symptoms.

Because of these facts, there was a difficulty in giving a percentage of the plants used for each ailment. So to simplify, the study grouped together related medical uses and then classify them into 20 types as shown Table 3 . The table does not indicate the frequency or prevalence of the ailments and diseases in the two villages. It shows that the number of species for treating stomach-related ailments as the most with 26 plants because it has a 
wide range of symptoms. The remedy for fever with common cold and its related symptoms like high temperature, dizziness, and coughs involved 14 plants as a distant second, while treatment of hypertension and cuts/wounds as a close third and fourth respectively involving 13 and 12 plants. Table 3 also shows that there were nine ailments that require a single or specific plant to treat each of them.

Table 3

Medicinal uses and number of plants involved

\begin{tabular}{lll}
\hline & Medicinal uses/ Purposes & $\begin{array}{l}\text { No. of } \\
\text { plants }\end{array}$ \\
\hline 1 & $\begin{array}{l}\text { To relief stomach-ache (Including diarrhea, gastric, constipation, } \\
\text { stomach ulcers, dysentery, flatulence) }\end{array}$ & 26 \\
2 & $\begin{array}{l}\text { Fever (to lower body temperature, cough, common cold, } \\
\text { headaches, etc) }\end{array}$ & 14 \\
3 & To alleviate hypertension & 13 \\
4 & Cuts/wounds including bruises & 12 \\
5 & Health & 7 \\
6 & For mothers after childbirth (includes regaining of strength and & 7 \\
7 & health/vigor, & \\
8 & To treat skin diseases (warts, ringworms, psoraissis, itchiness, etc) & 6 \\
9 & Diabetes and kidney disorders & 5 \\
10 & Boils & 2 \\
11 & To treat asthma & \\
12 & To treat joint pain & 2 \\
13 & To treat backaches & 2 \\
14 & Bone fractures & 1 \\
15 & Sprains & 1 \\
16 & Stroke & Jaundice in newborn baby \\
17 & Burns & 1 \\
18 & Treatment against liver diseases, & 1 \\
19 & Bladder infections & \\
20 & To relief tooth ache & 1 \\
\hline & & 1 \\
\hline
\end{tabular}

Based on Table 2, various parts of the plants were used for medicinal purposes while some plants have specific parts that can be used for treating ailments. For example, both the leaves and roots of Eurycoma longifolia (Tongkat Ali), Curcuma domestica (umiet), and Zingiber officinalis (Roie) can be used for medical purposes. In this case, the parts of the same plant were recorded twice: one for the foliage and another for the roots. Some other plants too have different parts that the informants mentioned have specific purposes such as the bark of Macaranga gigantean (Badad) for treatment of gastric when boiled together with Nepenthes ampularia (Tramuok), Blechnum orientale (Sonu) and Spatolobus sp. (Gomier). The case is similar to the flowers of Annona muuricata (Dien Belanda) which are used to lower down hypertension is considered as one part, though based other references such as Chai (2006) also stated the fruit has a role in counteracting the advance of cancer.

Similar to the difficulty for the medicinal uses of the plants, the percentage of plants based on the different parts here also cannot be calculated. Nonetheless, it can be summarized that there are eight common parts namely foliage, roots, fruits, roots, stems, barks, seeds and whole plants (Table 4). Foliage or twigs consisting of young leaves or shoots with or without young stems was the most coming from 36 plants. There were 12 plants whereby their fruits 
(which include beans, nuts, and berries as well as the flesh of the fruit such in the case of coconut) as the source of the medicinal part. With this number, the fruits stand as a distant second. The roots, which also include the other underground parts like rhizome and tubers, followed closely as third represented by nine plants. The stems and seeds, each contributed by three plants, stood as distant fourth while whole plant for two as sixth. The barks and flowers with each just obtained from their respective plant only were considered the least used. This trend is quite similar to those practiced else among the Bidayuhs (Weety,1997; Noweg and Jihen, 2005 and Noweg et. al. ,2006) and other communities in Sarawak (Chai, 2006).

Table 4

Plant parts used for herbal medicine and number of plants involved

\begin{tabular}{ll}
\hline \multicolumn{1}{c}{ Parts used } & No. of plants \\
\hline Foliage (young leaves and stems) & 36 \\
Fruit (beans, nuts, berries) & 12 \\
Roots including rhizomes and tubers & 9 \\
Stem & 3 \\
Seed & 3 \\
Whole plant & 2 \\
Bark & 1 \\
Flower & 1 \\
\hline
\end{tabular}

\section{Main method of administration and main ingredients used}

The methods of preparation and administration of the medicinal plants varies with plants and ailments intended to treat as shown in Table 2 above. The study then grouped related ones into a common group, resulting in 10 different groups as shown in Table 5.

From this table, decoction with 33 plants for drinking and five for bathing, tops the list, followed by eating or taking the medicinal plant part involving 19 plants as a distant second while pound and rub with 9 plants as third most common. The preparation of decoction depends on the types of plant parts used, they can be either fresh or further treatment necessary such as drying to the parts concerned before boiling in water or a mixture with other liquids such as a few drops of vegetable oil. This method is similar to what had been practiced by the malays in Terengganu (Ong et al, 2011). The mixture after boiling is the decoction, which be used as a drink or used in bathing. The latter use is usually for easing oneself during fever and treatment of the whole body such as to remove bad body odor as well as skin diseases that affect the whole body.

The pounding of the medicinal plant part and then rubbing or massage to the affected body parts method with nine plants while the chew and apply with five plants as the fourth most popular method. The pounding of the medicinal parts usually involved a few drops of water and/or other liquids such as vegetable oils. Similar to the decoction above, the medicinal plant arts could be fresh or need another process before pounded. Those plants are require chewing before topical application on the affected body parts are usually non-toxic. Four plants which are used in food as spice and to enhance their flavor came as fifth. It is not sure whether these plant parts are eaten later, although the two among them namely Zingiber officiale (Roie) and Piper nigrum (Lada) are actually consumed (Det et al, 2013). 
Table 5

Main method of administration and main ingredients used

\begin{tabular}{lc}
\hline Main method of administration and main ingredients used & No. of plants \\
\hline Decoction, then drink involved 33 plants while 5 plants for bathing & 38 \\
Eaten & 19 \\
Pound and rub & 9 \\
Chewed and apply & 5 \\
Used in food preparation (spices, flavour) & 4 \\
Pound and bandage & 1 \\
Juice & 1 \\
$\begin{array}{l}\text { The plant with any other plant will be fanned on the patient's body while the shaman } \\
\text { giving an appropriate chant. }\end{array}$ & 1 \\
$\begin{array}{l}\text { Boil the leaves in a big pot then place under a chair while mother is sitting on the } \\
\text { chair. }\end{array}$ & 1 \\
$\begin{array}{l}\text { Warm the leaves over a fire and apply on the abdomen of the mother and apply onto } \\
\text { bruises }\end{array}$ & 1 \\
\hline
\end{tabular}

\section{CONCLUSION}

Although the communities at Jagoi area is well connected to modern medical facilities and medicines, some of them they still use them occasionally since they knew their uses and cost them lesser as compared to conventional medicine.

The survey revealed that at least 58 species of medicinal plants from 38 families are being used by the communities there. Close to $60 \%$ of these plants are found wild in the fallows and nearby Mount Jagoi forest while the rest are planted at the backyard and/or gardens close to their village. Most of the cultivated medicinal plants were also used as food or often used in their preparation to enhance their flavor. The main reason why they planted them was to enable them obtained easily when needed. Majority of the medicinal plants are herbs $(27.6 \%)$ followed by shrubs $(24.1 \%)$ and trees $(19.0 \%)$. Medicinal source derived from only two palms were considered the least (3.4\%). In terms of usage, the number of species for treating stomach-related ailments as the most followed by the remedy for fever-related illnesses, and treatment of hypertension and cuts/wounds respectively. Foliage or twigs as the most common part of the plants used followed by fruits and roots.

The common methods of preparation and administration of the medicinal plants, decoction tops the list, followed by ingestion and then pound and rub. The preparation of decoction depends on the types of plant parts used, they can be either fresh or further treatment necessary such as drying to the parts concerned before boiling in water or a mixture with other liquids such as vegetable oil. The mixture after boiling is the decoction, which be used as a drink or used in bathing. The latter use is usually for easing oneself during fever and treatment of the whole body such as to remove bad body odor as well as skin diseases that affect the whole body.

Noteworthy is that the study missed six species of medicinal plants from four families that are commonly used for food in the area which could be that the informants were not aware of the medicinal benefits. Should a future survey is being done in a community, it is recommended that the informants be also questioned their knowledge on those plants so that they too could be included. 
The study contributes to the knowledge of medicinal plants and their usage in Bau-Jagoi area and can potentially be representative of the practices among the Bidayuh as a whole

\section{ACKNOWLEDGEMENT}

The study was financially supported by Institute of Biodiversity and Environmental Conservation (IBEC) of UNIMAS through the research grant, grant no: 101/00/BUNG JAGOI under Jagoi Area Development Committee Project funded by GEF UNDP Malaysia. We also thanks to all the key informants involved during the study: Miku Angik Ak Megan (Jagoi Duyoh), Lipien Ak Gijud (Jagoi Duyoh), Jema Ak Nopis (Jagoi Gunong), Nyohid Ak Jambong (Jagoi Serasot), Aheng Ak Langgor (Jagoi Serasot), Rikep Ak Minet (Jagoi Serasot), and Ahsen Ak Nyokew (Jagoi Serasot). 


\section{REFERENCES}

Ahmad, F. (1993). Medicinal plants used by Kadayan community in Sarawak. The Sarawak Museum Journal 65: 45- 58.

Chai, P. P. K. 2006. Medicinal Plants of Sarawak. 212 pages. Lee Ming Press, Kuching, Sarawak.

Christophe, W. (2006). Medicinal Plants of Asia and the Pacific. London, N.Y: CRC Press.

Martin, G. (1995). Ethnobotany. A 'People and Plants' Conservation Manual. (WWF International, UNESCO, Royal Botanic Gardens, Kew, UK, Chapman \& Hall).

Migas, O. K. 2012. Species Composition of Mixed Dipterocarp and Heath Forest: A Case Study at Jagoi, Bau, Sarawak. BSc Thesis Unpl. 50pages. Universiti Malaysia Sarawak

Noweg, G.T. \& Jihen, B. (2005). Wild Plants used as Traditional Medicine to Treat Minor Illness or Ailments in the Bidayuh Community in Bau District, In: Biological Resources of Western Sarawak. Alek Tuen (ed). Institute of Biodiversity and Environmental Conservation, Universiti Malaysia Sarawak, Kota Samarahan.

Noweg, G.T., Razip, A.M., Tipot, E. and Liam, J. (2006). Medicinal plants of Loagan Bunut National Park, Sarawak. In: Scientific Journey Through Borneo: Loagan Bunut. Tuen, A.A., Sayok, A.K., Toh, A.N. and Noweg, G.T. (eds.)

Nuek, P. R. 2005. A Dayak Bidayuh Community Rituals, Ceremonies and Festivals. Lee Ming Press Sdn Bhd, Kuching, Sarawak.

Ong, H. C. Ruzalila, B. N. and Milow, P. 2011. Traditional knowledge of medicinal plants among the Malay villagers in Kampung Tanjung Sabtu, Trengganu, Malaysia. Indian Journal of Traditional Knowledge. Vol. 10(3):460-465.

Ripen, J. E. and Noweg G. T. (2016). Economic valuation of Medicinal Plants in Jagoi Area, Bau, Malaysia. Procedia- Social and Behavioral Science 224(2016) 124-131.

Runi, S. P. (2000). Studies on medicinal plant in Sarawak - Agris. agris.fao.org/agris -search/search.do? recordID $=$ MY2012050118

Sabariah, B. (edr). (2010). Tumbuhan ubatan Liar di Sekeliling Anda. Selangor, Malaysia: ArRisalah product Sdn. Bhd

Sabariah, B. (edr). (2010). Tanaman Hiasan Ubatan di Sekeliling Anda. Selangor, Malaysia: ArRisalah product Sdn. Bhd.

Salma, I, Khadijah, A., Raziah, M. L., Azuan, A., Rahman, M. A., Wong, W. W., \& Lau, C. Y. 2011. Contribution of home gardens and orchards to on farm conservation of underutilsed fruit trees. In Mohd Shukor Nordin, Salma Idris, Mohamed Rani Mat Yusof and Mohd Shukri Mat Ali (eds). Agrobiodiversity in Malaysia II: Conservation and Sustainable Utilization. Malaysia Agricultural Research and Development Institute (MARDI) and Bioversity International. 
Sayok, A. K., Noweg, G. T. \& Pahon, I W. (2014). Jagoi Heritage: A peek at the ancestral sites, forest and community. Universiti Malaysia Sarawak and Jagoi Area Development Committee. 90pages.

Tawan, C.S., Alwin, G.J., Ipor, I.B., \& Meekiong, K. (2009). Medicinal Plants of the Malay community in Kota Samarahan District, Sarawak. UNIMAS Special Focus on Biodiversity-Research Update 5(2): 7.

Tipot, E., Liam, J. \& Sayok, A.K. (2006). Tumbuhan ubatan di Taman Negara Loagan Bunut. Kepong, Malaysia: Institut Penyelidikan Perhutanan Malaysia (FRIM), pp.91

Toiang, A. A. 2016. Utilisation and Valuation of Non-Timber Forest Products in Jagoi Area: A Case Study of-Kampung Duyoh, Bau District, Sarawak. Unpubl. MSc Thesis. 76 pages. Universiti Malaysia Sarawak.

Weety, M. (1997). Tumbuhan ubatan Masyarakat Bidayuh di Daerah Bau, Sarawak. Unpublished Bsc. Thesis. University Malaysia Sarawak. 